\title{
Occurrence of manganese ores in different tectonic settings in the NW Himalayas, Pakistan
}

\author{
Mohammad T Shah \\ National Centre of Excellence in Geology, University of Peshawar, Peshawar, PAKISTAN \\ For correspondence, E-mail: tahir_shah56@yahoo.com
}

In Pakistan, the occurrences of manganese ores have been reported in the Hazara area of North West Frontier Province, Kuram, Bajaur and North Waziristan agencies and the LasbelaKhuzdar regions of Baluchistan. Thisstudy is mainly focused on the comparison of mineralogy and geochemistry of the manganeseores of Hazaraand North Waziristan areas of Pakistan. The former occurs in the continental while the latter occurs in theophiolitic sequences. In Hazara area, theferromanganeseores are present in three localities (i.e., Kakul, Galdanian and Chura Gali) near Abbottabad within the Hazira Formation of the Kalachitta-Margala thrust belt of the NWHimalayas of thelndoPakistan plate. The Hazira formation of Cambrian age is a relatively thin unit (up to $150 \mathrm{~m}$ thick) of reddish-brown ferruginous siltstone, with variable amounts of clay, shale, ferromanganese ores, phosphorite and barite. It has a conformable lower contact with the Abbottabad Formation (Cambrian) and an unconformable upper contact with the Samana Suk limestone (Jurassic). In Waziristan area, the manganese ores occur in two localities (i.e., Saidgi and Barazai) within theWaziristan ophiolitecomplex, which is located al ong the western margin of the Indian platein thenorth-western part of Pakistan. These ores, both banded and massive in nature, are hosted by metachert and generally overlying the metavolcanics.

Mineralogicaly, theferromanganeseores of Hazara area are divided into Kakul-Galdanian and Chura Gali ores. The KakulGal danian ores contain relatively morehematiteand less $\mathrm{Mn}$-Fe phases such as bixbyite, partridgeite, hollandite, pyrolusiteand bruinite than those of Chura Gali. Bixbyite and partridgeite are the dominant $\mathrm{Mn}$-bearing phases in these ores. Among the gangue minerals iron-rich clay, alumino-phosphate minerals, apatite, bariteand glauconite are present in variable amount in both the ore types. The textural behavior of the ore phases suggests recrystallization and remobilization during greenschist facies metamorphism. The Waziristan ores are dominantly composed of braunite with lesser amount of bixbyite and pyrolusite. Hematiteoccurs asadditional minor phasein theores of Shuidar area. Cryptocrystallinequartz is theonly silicatephase occurring in these ores.

Chemically, composition of the Hazara ores differs from those of the Waziristan. In Hazara ores, $\mathrm{Mn}$ /Fe ratio is highly variableand ranges from 0.46 to 5.25 . These ores exhibit a line of descent from LREE to HREE with a small positive Ce anomaly. Their $\Sigma$ REE is higher than the hydrothermal $\mathrm{Mn}$ deposits and lower than the hydrogenous crust. TheWaziristan ores are having $\mathrm{Mn} / \mathrm{Fe}$ ratio in the range of 3 to 755 . Their Major and trace elements data as well as the REE pattern, showing deep negative Ceanomaly, istypical of thesubmarinehydrothermal manganese ores. The petrochemical characteristics suggest that the ferromanganese ores of Hazara area have originated by a mixed hydrothermal-hydrogenetic source in shallow water or continental shelf environment due to the upwelling of anoxic deep seated water while the Waziristan manganese ores were formed along the sea-floor spreading centers within the NeoTethys Ocean and were later obducted as part of the ophiolite complex. 